\title{
Exploring Future Effects of Prolonged Austerity Policy on Environmental Decisions in Scotland: Perspectives from a Kuznetsian Thought Experiment
}

\author{
Vincent Onyango, PhD \\ Architecture \& Urban Planning, \\ University of Dundee, Scotland, United Kingdom
}

Doi:10.19044/esj.2020.v16n22p287 URL:http://dx.doi.org/10.19044/esj.2020.v16n22p287

\begin{abstract}
The austerity policy atmosphere pursued by most European governments post 2007/8 financial crises, resulted in significant budgetary cuts to environmental protection institutions, meaning that more needed to be done with fewer resources. This raises a fundamental question: if resources or financial income for institutions that promote environmental protection drop or stop growing, as during recent austerity, how would this affect future environmental protection decisions? In response, this paper applied the Environmental Kuznets Curve (EKC) model as a thinking tool, to project and link "budgetary income" for environmental protection institutions and the "perceived environmental protection", within a context of prolonged austerity policy atmosphere. The data for budgetary income and for perceived environmental protection was collected from published documents and questionnaire surveys, respectively, in Scotland, from stakeholders involved in the planning sector. The results showed a high likelihood of continued adverse effects on environmental protection, suggesting that a new debate towards a fundamental approach in how to protect the environment during prolonged periods of financial hardship is urgently needed. The paper concludes that there is an urgent need to overcome the powerful state rhetoric and rationale that puts neoliberal exigencies of economic revitalisation above considerations of environmental protection.
\end{abstract}

Keywords: Austerity, Environmental decisions, Scotland, Environmental Kuznets Curve, Neo-Gramscian influence

\section{Introduction}

In economic terms austerity is defined as a set of economic policies aimed at reducing public budget deficits and debts, ostensibly, to restore balance in government finances (Tobin and Gravey, 2015; Cheyne, 2015; 
Kitson et al., 2011) and regain economic dynamism and competitiveness (Westbury and Stein, 2010; Reinhart and Rogoff, 2013). Since 2010, austerity measures, mainly comprising spending cuts, tax increases or a mixture of both, have become a generalised policy reality as governments aim to deliver economic recovery by instilling financial efficiency and fiscal discipline (Blyth, 2013; Bracci et al., 2015). At the same time, a growing body of literature argues that in times of economic crisis, environmental concerns are likely to be put on the back burner (Tobin and Burns, 2015; Gazzola, 2013). According to Russel and Benson (2014), recent austerity measures favoured the economy at the expense of the environment, primarily, by reflecting a reduction in the ambition and aspiration of policies to protect the environment.

However, the long-term legacy of austerity measures on environmental protection remains largely unknown, with Lloyd (2011) indicating that the effects of austerity on planning sector decisions remain speculative in the short-term, as well as in the long-term (Onyango et al., 2019). Yet this matters within the conventional wisdom that planning helps societies set visions of desired futures and meet goals of sustainable development, including addressing current issues including biodiversity, climate change, resource efficiency and conservation, equity and governance (Allmendinger, 2009; Wilson and piper, 2010). Although decision-making support tools such as Environmental Assessment (EA) exist to ensure that the benefits and costs of planning decisions are weighed against potential negative environmental outcomes during decisions-making (Therivel and Partidario, 1996; Fischer, 2007), the pressures for economic revitalisation during austerity may have changed EA outcomes (Gazzola, 2013).

This suggests that environmental degradation, and by contrast environmental protection, is a function of the impact of global influences and domestic policy choices on the underlying forces driving environmental change in a region (see Dauvergne, 1997). This raises a fundamental question: if resources or financial income for institutions that promote environmental protection drop or stop growing, as during recent austerity, how would this affect future environmental protection decisions? As argued in Parkhurst (2017), only when implications of decisions and associated actions are known and considered, can better quality decisions to protect the environment be made.

To explore the above question, this paper aims to apply the Environmental Kuznets Curve (EKC) model (Cole et al., 1997) as a thinking tool, to project and link "budgetary income" for environmental protection institutions and the "perceived environmental protection", within a context of prolonged austerity policy atmosphere. As research on the environmental consequences of financial crises such as austerity is often constrained by data limitations, a thought experiment has the advantage of considering a 
hypothesis, theory, or principle, and then helping to think through its consequences without necessarily undertaking an actual experiment (Yeates, 2004). Thought experiments include scenario approaches that offer a means for dealing with critical issues of indeterminacy, innovation, reflexivity and framing in analysing change in socio-economic systems, paving the way for a coherent way of handling of socio-economic futures in impact assessment (Berkhout et al., 2002). Insight from such scenarios not only offer more empirical knowledge about a phenomenon but can also inform debate about what to do.

A key assumption is that the planning system, as part of a country, can be subject to the EKC hypothesis, following Neumayer (2003) and Arrow et al. (1995) who acknowledged that institutions especially from rich developed countries can significantly fight back and help avoid environmental degradation. At a theoretical and conceptual level, the EKC application therefore offers a robust platform to test the interface and dynamics between economics, socio-political behaviour and environmental status. Although this paper is essentially environmental in focus, it borrows an idea from economics, to enhance our understanding of a phenomenon that is crossdisciplinary.

Initiated by Simon Kuznets (Kuznets, 1955) in the 1950s and '60s and first used to analyse the relationship between the environment's health and the economy by Grossman and Krueger (1991), the EKC has become a standard feature in the technical literature of environmental policy (Yandle et al., 2002; Roberts and Thanos, 2003; Stern, 2004). It is best understood as a hypothesized relationship between environmental quality and economic development, positing that various indicators of environmental degradation tend to get worse as economic growth occurs, until average income reaches a tipping point, after which the curve reverses (Grossman and Krueger, 1991, 1994; Dinda, 2005). Underpinned by the idea that the demand for environmental quality is greater when income grows, and vice versa, in effect, it makes a bold statement that the solution to pollution or environmental degradation is economic growth (Figure 1). 


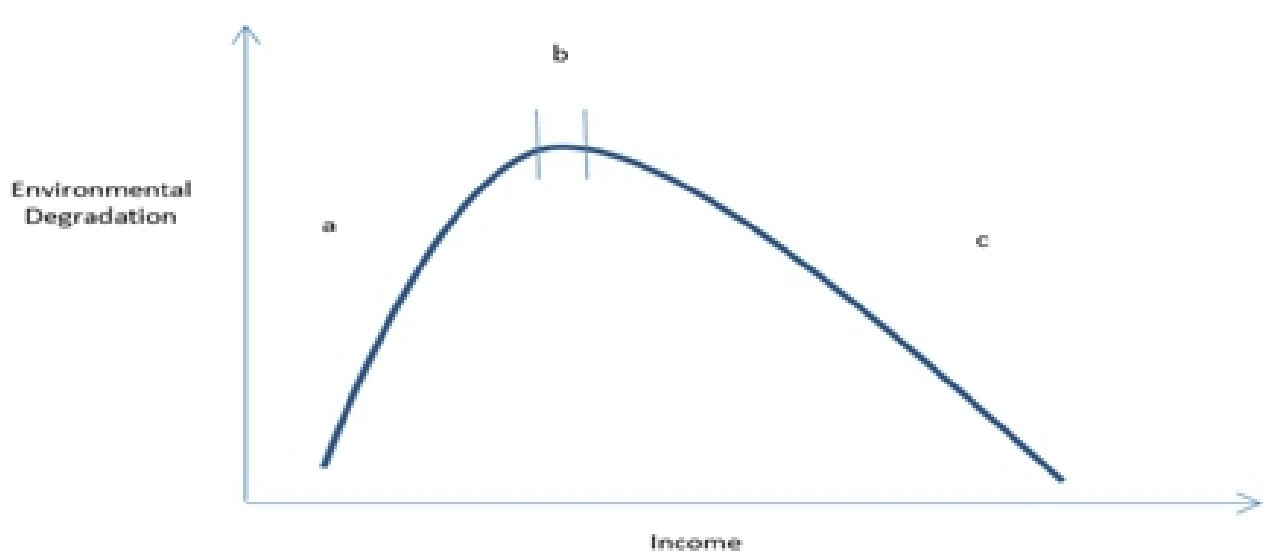

Figure 1. In the early stages of economic development environmental degradation will increase (phase a) until a certain level of income is reached (turning point (phase b)) and then environmental improvement will occur (phase c) (Based on Kuznets (1955) and Dinda (2005)).

While others have taken the EKC to mean grow now, clean up later (World Bank, 2005), critics have argued that there is no guarantee that economic growth leads to an improved environment. This leaves the EKC contentious as many confirmatory (Tierney, 2009; Levinson, 2000) and nonconfirmatory reports (Stern, 2004; Arrow et al., 1995; Du Pont, 2006) exist. For example, global $\mathrm{CO}_{2}$ has yet to prove its validity within EKC (Uchiyama, 2016) and some countries have disobeyed the EKC by 'exporting' their deforestation (Meyfroidt et al., 2013). Nevertheless, proponents of EKC maintain that this varied relationship does not necessarily invalidate the hypothesis, and that applicability of EKC may differ across various environmental indicators, ecosystems, economics, regulatory schemes, and technologies.

Other researchers have argued that the shape of the curve, when longer-term time scales are evaluated, follow an $\mathrm{N}$ shape, with pollution increasing as a country develops: decreasing once the threshold GDP is reached, and again increasing as national income continues to rise (Mills and Waite, 2009). Although traditionally linking two structural data variables, GDP and demand for environmental goods, this study will explore the future implications of recently observed impacts of austerity measures on environmental protection decisions. It builds on increasing evidence that austerity has negatively impacted environmental protection decisions, generally based on international literature, and specifically, grounded on findings from Onyango et al.'s (2019) seminal study of how environmental protection decisions were affected by recent austerity policy atmosphere in Scotland's planning system. Following the introduction, the next section sets the relevant context to understand the paper, by outlining some theoretical 
perspectives and the knowledge gap to which this paper hopes to contribute. The methodology is subsequently explained, results presented and conclusions and recommendations are drawn.

\subsection{Austerity impacts on environmental decisions: key studies}

In terms of systematic studies to understand how austerity affects the environment, relatively little work has been undertaken. Studies in the USA (Levine and Posner, 1981; Peck, 2014) and the UK (Grimshaw, 2013) have found that austerity measures eroded state and local autonomy, causing subtle but fundamental changes in their scope and role in advancing environmental protection. Other reports show that recent austerity-led cuts to public institutions and services meant that environmental protection agencies had to meet increasing expectations with fewer resources (Early, 2016; Crouch, 2011; Lekakis et al., 2013). Whilst Evans (2011) concludes that there is no clear evidence that austerity leads to frugality and sustainable consumption, many agree that the politics of decision-making are underpinned by the 'development paradigm' and dominated by a commitment to 'economic growth’ (Poritt, 2007; Jackson, 2017, 2018).

This raises concerns over the extent to which environmental issues are likely to be superseded by economic considerations (Taylor, 2002; Gazzola, 2013; Cavoski, 2015). A special edition of the Accounting, Auditing and Accountability Journal (Bracci et al., 2015) provided a review of the effects of recent austerity, but with relatively little focus on how the environment was accounted for. The same can be seen in The Violence of Austerity (Cooper and Whyte, 2017), with only two out of 24 chapters on the environment. However, more scholars are starting to investigate austerity's impact on environmental policies (Tobin and Gravey, 2015; Russel and Benson, 2014; Elliot, 2011; Karamichas, 2015; Onyang et al., 2019).

Studies at European level found that environmental policy-making was adversely affected as follows (Knill et al., 2009; Jordan et al, 2013): (1) reductions in the number of indicators used to monitor and measure environmental quality and environmental policy budgets; (2) reductions in policy density; and (3) reductions in policy intensity. Policy density describes the extent to which a certain policy area is addressed by governmental activities, demonstrated in the number of policies and policy instruments that are applied. Policy intensity describes the breadth of legislative activity in a policy field, demonstrated in the difference between the number of adopted and abolished policies (Bauer and Knill, 2012).

A recent study based on stakeholders' perceptions in Scotland's planning sector (Onyango et al., 2019), concluded that austerity had subtle and adverse effects on environmental decisions. For example, reduced consideration of environmental standards had occurred with planning 
applications, albeit within the law; wind energy projects were allowed in unsuitable places like peatlands/wetlands, as part of job creation and fighting climate change agendas, and; new areas e.g. green fields were opened for development as part of the push for more renewable energy under the Green Economy rationale. Public sector planners were relatively more critical about austerity's touted benefits, including the view that it was possible to achieve more without compromising environmental protection; while private sector planners were less optimistic, echoing the sentiment that the planning system still held up development (Brodies, 2015). Although this sentiment had been the case for some time (Lord and Tewdwr Jones, 2014) the participants in the study indicated that it had intensified during austerity.

Doubts were also expressed over the efficacy of existing decisionmaking support tools such as EA, which should help protect the environment, stating that the recent austerity period was a missed opportunity to further integrate the environment into planning decisions. The Onyango et al. (2019) study exposed a situation where under the austerity-driven rhetoric and imperative of revitalising the economy, decisions were made to boost the economy whilst clutching onto ideals of environmental protection, even when elements of the environment were being exposed to degradation. Although the Scottish Government was against austerity (Brooks, 2016; McHendrick et al., 2016), and besides its exemplary regime for environmental protection (Jackson and Illsley, 2006), 60\% of its budget comes from the UK government (Scottish Parliament, 2011) making it vulnerable to austerity measures imposed by the UK government.

\subsection{The hegemonic perspective}

Most of the relevant studies (sec 1.1) were much aware of the neoliberal hegemony of austerity (Cavoski, 2015; Jordan et al., 2013; Waterhout et al., 2012). At the centre of this hegemony was the narrative and rhetoric where goals of 'economic revitalisation', 'efficiency', 'cost-effectiveness', 'new ways of doing things', etc., were singularly pursued above other goals such as those of the environment. These narratives represented state and government-espoused agenda, which subsequently permeated and domineered through the planning system, underpinned by a plethora of powerful and complex multi-level government-supported means and agents e.g. budgets and targets of planning departments (Onyango et al., 2019; Gill, 2002). Some regulatory requirements on environmental protetion were reported to be 'relaxed' without any formal changes to the regulations themselves; projects were permitted on environmental assets where they would not have been allowed pre-austerity, and; even stakeholders who were traditionally known to protect the environment (e.g. environmental NGOs) became somewhat aligned 
to the government's agenda of revitalising the economy - showing just how deep the predominance of the government's agenda went.

This hegemony which is a widely acknowledged theory of neoliberalism that tends to favour free-market capitalism (Vincent, 2009; Pradella and Marois, 2015), describes the integration of environmental policy as a normative enterprise that is ab initio shaped and influenced by the principles and values of neoliberalism. According to Humphreys (2015), thus limiting the successes of policies to protect the environment. Furthermore, Onyango et al. (2019) resorted to the refined social theory hypothesis of NeoGramscianism (Cox, 1981, 1983) to provide a theoretical lens for explaining why the austerity ideology pursued in the UK jurisdiction took effect in another jurisdiction which was officially opposed to austerity i.e. Scotland (Scottish Government, 2016).

Neo-Gramscianism also views the state as able to exercise hegemony via the machinery of government and its many organs and institutions, through which it can exert influence, e.g. via budgets, regulatory instruments, media and mass culture, to establish hegemonic power relations (Goodman and Salleh, 2013). However, there is no convincing explanation as to why the hegemony of neoliberalism should necessarily be associated with adverse environmental decisions. This invites fundamental discussions yet to be had and resolved, about the spirit and purpose of current planning thinking and practice, to contend with the ideological imperatives introduced by the post 2007/08 austerity policy atmosphere (Lloyd, 2011). With matters such as climate change requiring long-term solutions (House of Commons, 2016; Rockström et al., 2009) and more resilient approaches to planning (Davoudi et al., 2012) it becomes crucial that the long-term impacts of austerity on environmental decisions are understood and effectively addressed.

\section{Materials and methods}

To apply the EKC thought experiment, the horizontal axis of the standard EKC was substituted with "budgetary income" for key environmental institutions and the vertical axis was substituted with "adverse environmental impacts". This nexus allows the impacts as a result of interactions between austerity and environmental protection issues to be mapped across time. The cutting of budgets to Scotland's key environmental protection institutions, as a result of austerity, can be seen in Table 1. 
Table 1. Overall reductions in departmental level-funding for key Scottish governmental departments involved in environmental protection (2009/10-2016/17). Sources: Adapted from annual Scottish Spending Reviews and Budgets (DEFRA, 2016; Scottish Parlianment, 2011).

Based on draft budgets and sums represent Grant-In Aid from the Scottish Government.

\begin{tabular}{|c|c|c|c|c|c|c|c|c|c|}
\hline & $\begin{array}{c}2008 / \\
09\end{array}$ & $09 / 10$ & $10 / 11$ & $11 / 12$ & $12 / 13$ & $13 / 14$ & $14 / 15$ & $15 / 16$ & $16 / 17$ \\
\hline SNH & - & 67.9 & 67.9 & 60.7 & 57.8 & 55.3 & 53.1 & 53.1 & 48.4 \\
\hline SEPA & - & 35.2 & 44.3 & 39.4 & 38 & 37.5 & 37.5 & 39 & 36.6 \\
\hline MS & & 75.5 & 62.4 & 55.9 & 54.3 & 49 & 48.4 & 47.9 & 45.8 \\
\hline Planning & 9.1 & 7.5 & 4.9 & 3.6 & 4.1 & 3.8 & 5 & 4.2 & 4.1 \\
\hline
\end{tabular}

Three possible future austerity scenarios were identified and their likely trajectories of environmental degradation traced on the graph. These aimed to cover the broad spectrum between the two extremes: one where austerity's narratives and hegemony are supreme and the other where an ideal environmental protection decision-making system, which can adequately countermand any or tendencies of hegemony from austerity, exists. Scenario one acknowledged the supremacy of the EKC hypothesis, strongly underpinned by the idea that the demand for environmental quality is greater when income grows, and vice versa, emphasizing a prominent income elasticity of demand for environmental quality. Scenario two acknowledged the view that the EKC hypothesis can partly and to some degree be counteracted by existing institutional and environmental protection frameworks.

Thus, relevant institutions can in a situation where austerity is resulting in adverse environmental decisions, necessarily respond and correct the situation. Scenario three is the opposite of scenario one, and assumes the existence of an effective decision-making system that is fit-for-purpose and capable of assuring environmental protection, regardless of the financial/economic hardships, including exigencies associated with austerity (Table 2).

Table 2. Various scenarios tested in the thought experiment, in austerity situations where budgets to planning and environmental protection agencies are assumed to have steadily fallen.

\begin{tabular}{|l|l|}
\hline Scenario & Assumed conditions \\
\hline 1. Business as usual & $\begin{array}{l}\text { Sustained fall in budgets and financial resources; strong } \\
\text { austerity policy atmosphere; neoliberal austerity imperatives } \\
\text { are largely unchallenged }\end{array}$ \\
\hline 2. Mid-range optimism & $\begin{array}{l}\text { Sustained fall in budgets and financial resources; existing } \\
\text { environmental protection institutions and laws are responsive } \\
\text { but not adequately; weak hegemony of austerity's neoliberal } \\
\text { imperatives }\end{array}$ \\
\hline
\end{tabular}


3. Most optimistic (fitfor-purpose decisionmaking framework exists)
Sustained fall in budgets and financial resources; strong austerity policy atmosphere; BUT robust decision-making systems in place and environmental concerns not unduly dominated by economic exigency; economic responses decoupled from environmental degradation.

\section{Results and findings}

The first scenario, following the standard EKC principles, starting from point $\mathbf{x}$, revealed a reversal of the curve from zones $\mathbf{c}-\mathbf{b}-\mathbf{a}$, but to a final range between D1-E1 and D2-E2 (Figure 2). Although reduced income is a dominant factor in determining the EKC trajectory, this is not a perfect reversal as some lessons in environmental protection from past experiences will have been learnt by stakeholders and environmental protection agencies in Scotland.

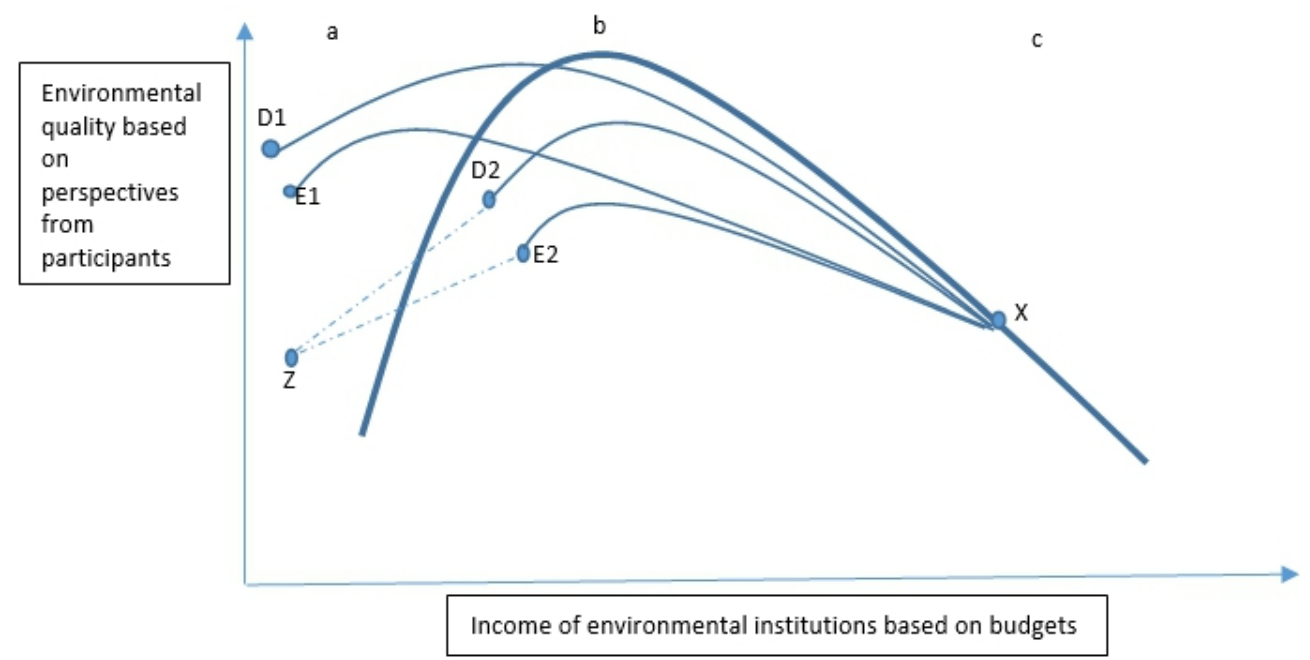

Figure 2. Generated curves in scenario one, the Business as Usual case. Curves D1 and E1 show slower respnse nad longer lag; D2 and E2 show quicker response.

The D1-E1 trajectories show two boundaries of poor environmental protection, whilst the D2-E2 trajectories show more effective avoidance of environmental degradation, but still at a level worse than the initial level $\mathbf{x}$. The D1-E1 trajectories could also signify a weaker influence of the austerity atmosphere whilst the D2-E2 trajectories could signify a stronger effect. These cuts could also be 'too far, too fast', and not allowing for appropriate adjustments to assure continued environmental protection aspirations: triggering trajectories to point $\mathbf{z}$. Scenario two (Figure 3) revealed a sinuous trajectory, the path from c-b-a being more ameliorated by the existing infrastructure for environmental protection. 


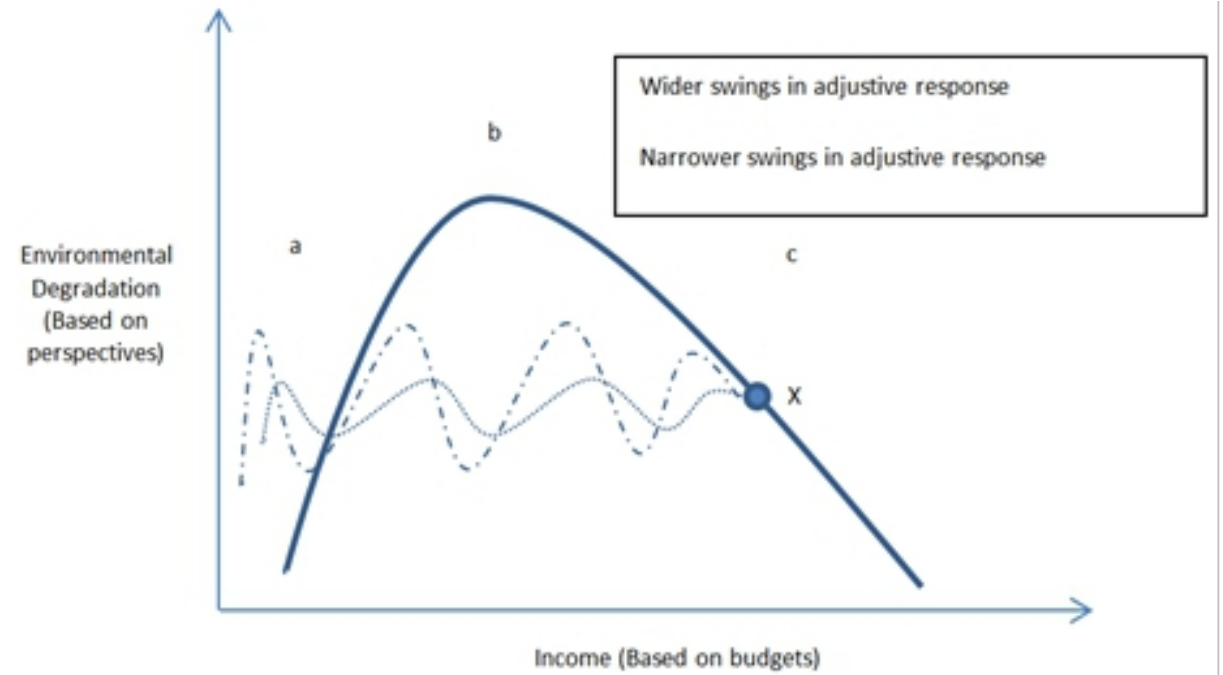

Figure 3: Scenario two where EKC hypothesis is dominated by the mitigatory effects from established environmental protection infrastructure. The upper dashed curve shows more latitude from less effective ameliorative effects; the lower dotted curve shows lower tolerance for environmental degradation.

Although income elasticity of demand is operational, the dominant factor in determining this trajectory comes from the limited but constraining effects of the established infrastructure for environmental protection, e.g. lessons learnt from years of experience in EA-aided decision-making. These ameliorative or corrective decisions effects are reactive in nature and therefore have a time lag, thus the sinuous trajectories.

This is because as budgets for planning and environmental protection institutions fall, the EKC hypothesis kicks in and environmental degradation follows, and the cycle repeats itself, leading to a range between the two sinuous curves: slightly above $\mathbf{x}$ at the worst or below $\mathbf{x}$ at the best, respectively. The point below $\mathbf{x}$ can occur, when environmental degradation is occurring innocuously or subtly as was indicated in the Scotland study (Onyango et al., 2019). For example, increasing greenhouse gases emissions or slow transformations in the greening of business supply chains, can be less visible and therefore not trigger immediate responses, as opposed to more visible and perhaps alarming degradation such as deforestation or waste pollution. It is also likely that the sustained budgetary cuts for environmental protection institutions reach a level where the capacity to deliver environmental protection is significantly curtailed, as resources for doing the work are considerably reduced (Cole and Neumayer, 2005), going to point $\mathbf{x}$ as shown in Figure 2. 
In scenario three, although the income elasticity of demand for environmental quality may be at play, this is effectively countermanded by a fit-for-purpose decision-making framework, driven by two factors working in tandem or isolation. One, following the EKC, that rich countries like Scotland can meet higher demands for environmental protection through their institutional and resource capacities as noted in Cole and Neumayer (2005). Two, many years of lessons-learnt and established environmental protection infrastructure, including regulations, institutions and public awareness towards appreciation of the environment, can ameliorate the EKC impetus. This is represented by the curves in Figure 3, with relatively lower amplitudes in comparison to curves in scenarios one and two (Figure 2), maintaining a fluctuating but reducing environmental degradation compared to the initial position of $\mathbf{x}$ : decoupling austerity's impacts from environmental quality.

\section{Discussion}

The EKC thought experiment provided seemingly reliable projections of how austerity could in the future affect environmental quality. Although the traditional usage of numerical values in EKC was not fully applied, the EKC concept in this study adds the advantage of being grounded on an established theoretical concept that links people's collective behaviour, economic situations and environmental quality (Yandle et al., 2002; Grossman and Krueger, 1991). Furthermore, the neo-Gramscian hypothesis also crept into the explaining of what was observed in the EKC models, as the mechanics of the hegemonic influence was partly integrated into the generated curves in the scenarios.

While providing a useful heuristic and prognosis, the EKC thought experiment nevertheless has limitations. For example, as already argued in some studies (Peters et al., 2011), it did not account for Scotland's relocation of environmentally polluting factories to other countries and/or shifting of environmental problems from one domain to another (Mills and Waite, 2009); as this would have perhaps shown more extreme downward movements in the curves in the scenarios. Moreover, the EKC has also been known to not work for all the pollutants that could degrade the environment (Stern, 2004). Therefore, as this paper's results are based on a pioneering thought experiment that is exploratory in nature, it is advised that the results be treated with caution until further tests using more data from other contexts, can establish issues of wider generalizability beyond the data from Scotland. Even if similar results may be generally observed, it is likely that the nature and level of details of the impacts and scope of trajectories will differ.

The results generally imply that in a situation of prolonged austerity, adverse impacts will obtain, unless a fit-for-purpose approach to environmental decision-making, which can robustly counterbalance 
austerity's exigencies, is established. Although this counterbalance appeared theoretically possible, however, the hegemony driven by coercive powers via the state's regulatory and budgetary instruments may make this difficult to obtain in practice. This neoliberal stance is appropriately explained by Lindblom's (1979, p. 533) 'valence issues' or 'taken for granted' issues, where the economy rather than the environment is automatically prioritised for consideration by politicians running for election or constructing budgets. Although some studies had found that institutions did adjust through a bricolage of measures, to cope with austerity (Lowndes and McCaughie, 2013, p. 544), the projections in this study suggest that this may not be enough to stem the adverse impacts from being realised. This leads to a troubling implication for future environmental protection, a conundrum resembling the classical wicked problem: how can an effective fit-for-purpose decision-making framework truly exist in the face of overwhelming neoliberal and NeoGramscian pressures, which tend to prioritize state-sponsored narratives and rhetoric to the exclusion of any other opposing or competing views?

In such a context, it is challenging to successfully deliver environmental protection, as planning decisions become unduly compromised by the politicoeconomic imperatives of the day. Similar hegemonic power relations have been identified in other works around environmental governance (see for example O'Faircheallaigh, 2010; Cashmore and Richardson, 2013; Hansen et al., 2013). Moreover, this is because the Neo-Gramscian construction of hegemony (see Gilpin, 1981; Cox, 1981), brings about a unison of economic and political aims, including intellectual and moral unity, on the universality of austerity, at least within a national narrative that is hard to resist.

\section{Conclusion}

Three takeaway messages emerge from this paper. Firstly, and generally, that the projected impacts of long-term austerity on environmental decisions, as occurs within the planning function, is likely to deteriorate with time. The challenge remains that the neoliberal hegemony of the austerity ideology, has perverse effects on future environmental decisions, from two main sources. The lack of adequate resources commensurate to the tasks; and the attitudinal and paradigm shift where even those who are traditionally at the forefront of protecting the environment become absorbed into the austerity narratives from government. Finally, from the study results, it is concluded that other countries facing future prolonged periods of austerity now have basic insight upon which to start reflecting on their potential outcomes for environmental protection.

This can help them benchmark their own exploratory studies, policy responses, or initiate debate for a decisions-making framework suitable to their context and purposes. It is long past the time to re-examine the assumed 
underlying philosophical principles that currently allow the hegemony of statesponsored economic exigencies. While Lindblom (1979) argued that decisionmaking within complexity is a form of 'muddling through' based on small or incremental steps - now that we are beginning to have evidence of austerity's long-term impacts, perhaps some form of more skilful and methodically strategic analysis should now help improve our decisions-making around environmental protection.

\section{References:}

1. Allmendinger, P. (2009). Planning theory. London: Palgrave Macmillan.

2. Arrow, K., Bolin, B., Costanza, R., Dasgupta, P., Folke, C., Holling, C.S., Jansson, B-O., Levin, S., Ma“ler, K., Perrings, C., \& Pimentel, D. (1995). Economic growth, carrying capacity and the environment. Science, 268, 520 - 521.

3. Bauer, M.W., and Knill, C. (2012). Understanding Policy Dismantling: An Analytical Framework. In Bauer, M.W., Jordan, A., GreenPedersen, C. \& Héritier, A. (Eds.). Dismantling public policy: preferences, strategies, and effects. Oxford: Oxford University Press, pp. 30-51.

4. Berkhout, F., Hertin, J., \& Jordan, A. (2002). Socio-economic futures in climate change impact assessment: using scenarios as 'learning machines. Global Environmental Change, 12(2), 83-95.

5. Blyth, M. (2013). Austerity: The History of a Dangerous Idea. New York: Oxford University Press.

6. Bracci, E., Humphrey, C., Moll, J., \& Steccolini, I. (2015). Public sector accounting, accountability and austerity: more than balancing the books? Accounting, Auditing and Accountability, 28, 878-908.

7. Brodies. (2015). Brodies' submission to the Scottish Government's Review of the Planning [online]

http://www.brodies.com/binformed/legal-updates/brodiessubmission-to-the-scottish-governments-review-of-the-planningsystem (Accessed 17 March 2017).

8. Brooks, L. (2016). Nicola Sturgeon attacks Westminsters's morally 'unjustifiable' austerity policy [online]

https://www.theguardian.com/politics/2015/feb/11/nicola-sturgeonattacks-westminster-austerity-policy (Accessed 23 February 2018).

9. Cashmore, M., \& Richardson, T. (2013). Power and environmental assessment: introduction to the special issue. Environmental Impact Assessment Review, 39, 1-4.

10. Cavoski, A. (2015). A post-austerity European Commission: no role for environmental policy? Environmental Politics, 24(3), 501-505. 
11. Cheyne, C. (2015). Changing Urban Governance in New Zealand: Public Participation and Democratic Legitimacy in Local Authority Planning and Decision-Making 1989-2014. Urban Policy and Research, 33, 416-432.

12. Cole, M.A., \& Neumayer, E. (2005). Environmental policy and the environmental Kuznets curve: can developing countries escape the detrimental consequences of economic growth? In Dauvergne, P. (Ed.): Handbook of Global Environmental Politics. Cheltenham: Edward Elgar, UK, pp. 298-318.

13. Cole, M.A., Rayner, A.J., \& Bates, J.M. (1997). The Environmental Kuznets Curve: An Empirical Analysis. Environment and Development Economics, 2, 401-416.

14. Cooper, V., \& Whyte, D (eds). (2017). The Violence of Austerity. London: Pluto Press.

15. Cox, R.W. (1983). Gramsci, Hegemony and International Relations: An Essay in Method. Millennium, 12(2), 162-175.

16. Cox, R.W. (1981). Social Forces, States and World Orders: Beyond International Relations Theory. Millennium: Journal of International Studies, 10(2), 126-155.

17. Crouch, C. (2011). The Strange Non-Death of Neo-Liberalism. Cambridge: Polity Press.

18. Dauvergne, P. (2000). Globalization and environmental change: Asia's 1997 financial crisis. Current History, 99, 389-395.

19. Davoudi, S. (2012). Resilience: A Bridging Concept or a Dead End? Planning Theory and Practice, 13(2), 299-333.

20. Department for Environment, Food and Rural Affairs (DEFRA). (2016) DEFRA Annual Report and Accounts 2015 - 2016 [online] https://www.gov.uk/government/uploads/system/uploads/attachment _data/file/547295/defra-annual-report-2015-2016-print.pdf.

(Accessed 9 January 2018).

21. Dinda, S. (2005). A theoretical basis for the environmental Kuznets curve. Ecological Economics, 53, 403-413.

22. Du Pont, P. (2006). Don't Be Very Worried, The truth about "global warming" is much less dire than $\mathrm{Al}$ Gore wants you to think [online] https://web.archive.org/web/20060615222424/http://www.op inionjournal.com/columnists/pdupont/?id=110008416 (Accessed 11 February 2017).

23. Early, C. (2016). Defra defends its performance and budget plans. [online] http://www.environmentalistonline.com/article/defradefends-its-performance-and-budget-plans. (Accessed 22 February 2018).

24. Elliott, E. (2011). Shades of green in East Asia: the impact of financial 
crises on the environment. Contemporary Politics, 17(2), 167-183.

25. Evans, D. (2011). Thrifty, green or frugal: Reflections on sustainable consumption in a changing economic climate. Geoforum, 42(5), 550557.

26. Fischer, T.B. (2007). Theory and Practice of Strategic Environmental Assessment - towards a more systematic approach. London: Earthscan.

27. Gazzola, P. (2013). Reflecting on mainstreaming through environmental appraisal in times of financial crisis - From 'greening' to 'pricing'? Environmental Impact Assessment Review, 41, 21-28.

28. Gilpin, R. (1981). War and Change in World Politics. Cambridge: Cambridge University Press.

29. Goodman, J., \& Salleh, A. (2013). The 'Green Economy': Class Hegemony and Counter-Hegemony, Globalizations. Crisis, Movement, Management: Globalizing Dynamics, 10 (3), 411-424.

30. Grimshaw, D. (2013). Austerity, privatization and levelling down: public sector reforms in the United Kingdom. In Vaughan-Whitehead, D. (Ed.): Public Sector Shock. Cheltenham: Edward Elgar Publishing, pp. 576-626.

31. Grossman, G.M., \& Krueger, A.B. (1991). Environmental impacts of a North American Free Trade Agreement. Cambridge MA: NBER Working Paper Series No. 3914.

32. Hansen, A.M., Kornov, L., Cashmore, M., \& Richardson, T. (2013). The significance of structural power in strategic environmental assessment. Environmental Impact Assessment Review, 39, 37-45.

33. House of Commons. (2016). Sustainability and HM Treasury, House of Commons Environmental Audit Committee, Fifth Report of Session 2016-17 HC 181. House of Commons, London.

34. Humphreys, D. (2015). Integers, integrants and normative vectors: The limitations of environmental policy integration under neoliberalism. Environment and Planning C: Government and Policy, 00, 1-15.

35. Jackson, T., \& Illsley B. (2006). Strategic environmental assessment as a tool of environmental governance: Scotland's extension of the European Union SEA Directive. Journal of Environmental Planning and Management, 49(3), 361-383.

36. Jackson, T. (2017). Prosperity Without Growth - Economics for a Finite Planet. London: Earthscan.

37. Jackson, T. (2018). The Post-Growth Challenge: Secular Stagnation, Inequality and the Limits to Growth. Ecological Economics, 156, 236242.

38. Jordan, A., Bauer, M.W., \& Green-Pedersen, C. (2013). Policy dismantling. Journal of European Public Policy, 20(5), 795-805. 
39. Karamichas, J. (2015). Prospects for Capacity-building for environmental policy under austerity. A comparative study of Greece and the UK. Paper presented at the UACES 45th Annual Conference. Bilbao, 7-9 September 2015.

40. Kitson, M., Martin, R., \& Tyler, P. (2011). The geographies of austerity. Cambridge Journal of Regions, Economy and Society, 4, 289-302.

41. Knill, C., Tosun, J., \& Bauer, M.W. (2009). Neglected Faces of Europeanization: The Differential Impact of the EU on the Dismantling and Expansion of Domestic Policies. Public Administration, 87(3), 519-537.

42. Kuznets, S. (1955). Economic Growth and Income Inequality. American Economic Review, 49, 1-8.

43. Lekakis, J.N., \& Kousis, M. (2013). Economic Crisis, Troika and the Environment in Greece. South European Society and Politics, 18(3), 305-331.

44. Levine, C.H., \& Posner, P.L. (1981). The Centralizing Effects of Austerity on the Intergovernmental System. Political Science Quarterly, 96, 67-85.

45. Levinson, A. (2000). The Ups and Downs of the Environmental Kuznets Curve [online]

http://units.georgetown.edu/economics/pdf/0108.pdf. (Accessed 11 March 2017).

46. Lindblom, C.E. (1979). Still muddling, not yet through. Public Administration Review, 39(6), 517-526.

47. Lloyd, M.G. (2011). Planning with austerity and anomie in a new world. Scottish Planner Journal of the RTPI Scotland Newsletter, 139, 1- 4.

48. Lord, A., \& Tewdwr-Jones, M. (2014). Is Planning "Under Attack"? Chronicling the Deregulation of Urban and Environmental Planning in England. European Planning Studies, 22(2), 345-361.

49. Lowndes, V., \& McCaughie, K. (2013). Weathering the perfect storm? Austerity and institutional resilience in local government. Policy and Politics, 41, 533-549.

50. McHendrick, J.H., Asenova, D., MacRae, C., Reynolds, R., Egan, J., Hastings, A., Mooney, G., \& Sinclair, S. (2016). Conceptualising Austerity in Scotland as a Risk Shift: Ideas and Implications. Scottish Affairs, 25(4), 451-478.

51. Meyfroidt, P., Lambin, E., Karl-Heinz, E., \& Thomas, H.W. (2013). Globalization of land use: distant drivers of land change and geographic displacement of land use. Current Opinion in Environmental Sustainability, 5(5), 438-444. 
52. Mills, J.H., \& Waite, T.A. (2009). Economic prosperity, biodiversity conservation, and the environmental Kuznets curve. Ecological Economics, 68(7), 2087-2095.

53. Neumayer, E. (2003). Weak versus Strong Sustainability: Exploring the Limits of Two Opposing Paradigms. Cheltenham: Edward Elgar.

54. O'Faircheallaigh, C. (2010). Public participation and environmental impact assessment: purposes, implications, and lessons for public policy making. Environmental Impact Assessment Review, 30, 19-27.

55. Onyango, V., Gazzola, P., \& Wood, G. (2019). The effects of recent austerity on environmental protection decisions: evidence and perspectives from Scotland. Management of Environmental Quality, DOI: 10.1108/MEQ-01-2019-0025.

56. Parkhurst, J. (2017). The Politics of Evidence: from Evidence Based Policy to the Good Governance of Evidence. London: Routledge.

57. Peck, J. (2014). Pushing austerity: state failure, municipal bankruptcy and the crises of fiscal federalism in the USA. Cambridge Journal of Regions, Economy and Society, 7, 17-44.

58. Porritt, J. (2007). Capitalism: As if the World Matters. London: Earthscan.

59. Pradella, L., \& Marois, T. (2015). Polarising Development: Alternatives to Neoliberalism and the Crisis. Pluto Press, London.

60. Peters, G.P., Davis, S.J., \& Andrew, R. (2011). A synthesis of carbon in international trade. Biogeosciences, 9, 3247-3276.

61. Reinhart, C.M., \& Rogoff, K.S. (2013). Debt, Growth and the Austerity Debate [online]

https://www.nytimes.com/2013/04/26/opinion/debt-growth-and-theausterity-debate.html. (Accessed 21 November 2018).

62. Roberts, J.T., \& Thanos, N.D. (2003). Trouble in Paradise: Globalization and Environmental Crises in Latin America. Routledge, London and New York.

63. Rockström J., Steffen, W., Noone, K., Persson, Å., Chapin, F.S., Lambin, E.F., Lenton, T.M., Scheffer, M., Folke, C., Schellnhuber, H.J., Nykvist, B., de Wit, C.A., Hughes, T., van der Leeuw, S., Rodhe, H., Sörlin, S., Snyder, P.K., Costanza, R., Svedin, U., Falkenmark, M., Karlberg, L., Corell, R.W., Fabry, V.J., Hansen, J., Walker, B., Liverman, D., Richardson, K., Crutzen, P. and Foley, J.A. (2009). A safe operating space for humanity. Nature, 461, 472-475.

64. Russel, D., \& Benson, D. (2014). Green Budgeting in an Age of Austerity: a Transatlantic Comparative Perspective. Environmental Politics, 23, 243-262.

65. Scottish Government. (2016). Time to end austerity [online] http://news.gov.scot/news/time-to-end-austerity. (Accessed 15 March 
2018).

66. Scottish Parlianment. (2011). Justice Committee Report on the Draft Budget 2011-12. SP Paper 564. Annex I, FI/S3/11/R2, Volume 3 [online]

http://archive.scottish.parliament.uk/s3/committees/finance/reports11/fir11-02-vol202.htm. (Accessed 15 March 2018).

67. Stern, D.I. (2004). The Rise and Fall of the Environmental Kuznets Curve. World Development, 32(8), 1419-1439.

68. Taylor, J. (2002). Sustainable development - a dubious solution in search of a problem. Policy Analysis, 449, 1-49.

69. Therivel, R., \& Partidario, M.R. (1996). The Practice of Strategic Environmental Assessment. London: Earthscan.

70. Tierney, T. (2009). The Richer-Is-Greener Curve [online] https://tierneylab.blogs.nytimes.com/2009/04/20/the-richeris-greener-curve/. (Accessed 15 January 2018).

71. Tobin, P., \& Gravey, V. (2015). Exploring the Impacts of Austerity on Environmental Policy [online]

http://environmentaleurope.ideasoneurope.eu/2015/09/04/austerityenvironmental-policy/. (Accessed 25 March 2018).

72. Tobin, P., \& Burns, C. (2015). Measuring the Impact of Austerity on European Environmental Policy [online]

https://www.psa.ac.uk/sites/default/files/conference/papers/2015/The $\% 20$ Impact $\% 20$ of\%20Austerity\%20on\%20Environmental\%20Policy $\% 20$ Tobin\%20and\%20Burns\%202015\%20PSAfin.pdf. (Accessed 25 March 2018).

73. Uchiyama, K. (2016). Environmental Kuznets Curve Hypothesis and Carbon Dioxide Emissions, Springer. Springer Briefs in

Economics. doi:10.1007/978-4-431-55921-4.

74. Vincent, A. (2009). Modern Political Ideologies. Wiley-Blackwell, Hoboken New Jersey.

75. Waterhout, B., Othengrafen, O., \& Sykes, O. (2012). Neoliberalization Processes and Spatial Planning in France, Germany, and the Netherlands: An Exploration. Planning Practice and Research, 28(1), 1-19.

76. Westbury, B.S., \& Stein, R. (2010). Government Austerity: The Good, Bad and Ugly [online]

https://www.forbes.com/2010/07/26/government-spending-taxes-

opinions-columnists-brian-wesbury-robert-stein.html\#5b35424226e0. (Accessed 15 March 2018).

77. Wilson, E., \& Piper, J. (2010). Spatial planning and climate change. Routledge, Abingdon.

78. World Bank. (2005). Environment strategy for the World Bank in East 
Asia and the Pacific region. World Bank, Washington DC.

79. Yandle, B., Vijayaraghavan, M., \& Bhattarai, M. (2002). The Environmental Kuznets Curve: A Primer, PERC Research Study [online] https://www.perc.org/2004/04/16/environmental-kuznetscurves/. (Accessed 02 December 2018).

80. Yeates, L.B. (2004). Thought experimentation: a cognitive approach [thesis]. University of New South Wales. 